\title{
The Diagnosis and Treatment of Giant Cell Arteritis
}

\author{
Thomas Ness, Thorsten A. Bley, Wolfgang A. Schmidt, Peter Lamprecht
}

\section{SUMMARY}

Background: Giant cell arteritis (GCA) is the most common systemic vasculitis in persons aged 50 and above (incidence, 3.5 per 100000 per year). It affects cranial arteries, the aorta, and arteries elsewhere in the body, e.g., in the limbs.

Methods: We selectively review the pertinent literature, including guidelines and recommendations from Germany and abroad.

Results: The typical symptoms of new-onset GCA are bitemporal headaches, jaw claudiacation, scalp tenderness, visual disturbances, systemic symptoms such as fever and weight loss, and polymyalgia. The diagnostic assessment comprises laboratory testing (erythrocyte sedimentation rate, C-reactive protein), imaging studies (duplex sonography, high-resolution magnetic resonance imaging, positron-emission tomography), and temporal artery biopsy. The standard treatment is with corticosteroids (adverse effects: diabetes mellitus, osteoporosis, cataract, arterial hypertension). A meta-analysis of three randomized controlled trials led to a recommendation for treatment with methotrexate to lower the recurrence rate and spare steroids. Patients for whom methotrexate is contraindicated or who cannot tolerate the drug can be treated with azathioprine instead.

Conclusion: Giant cell arteritis, if untreated, progresses to involve the aorta and its collateral branches, leading to various complications. Late diagnosis and treatment can have serious consequences, including irreversible loss of visual function.

\section{Cite this as:}

Ness T, Bley TA, Schmidt WA, Lamprecht P:

The diagnosis and treatment of giant cell arteritis.

Dtsch Arztebl Int 2013; 110(21): 376-86.

DOI: 10.3238/arztebl.2013.0376
$T$ he typical symptoms and findings of giant cell arteritis (GCA) are still too often misinterpreted, and urgently needed treatment is delayed. Often, head and muscle pain in older patients are wrongly assessed for weeks, or patients are not referred to an ophthalmologist until they have become blind in one or both eyes.

GCA was first described clinically in 1890 under the name "arteritis of the aged," and later histologically characterized by Horton et al. (1). It manifests in patients over the age of 50 years and is associated in about half of the cases with polymyalgia rheumatica (PMR).

The earlier term "arteritis temporalis," once often used as a synonym, was abandoned in the internationally current Chapel Hill Consensus Conference (CHCC 1994) nomenclature, because not all patients with GCA have involvement of the temporal artery (2). Moreover, in rare cases the temporal artery may be affected in other forms of vasculitis, for example in granulomatosis with polyangiitis (Wegener).

These secondary forms must be distinguished from GCA, which makes it essential not to use "temporal arteritis" and GCA as synonyms. In the 2012 revised version of the CHCC nomenclature, GCA is defined as a large-vessel vasculitis, affecting the aorta and its large arterial branches more often than do other vasculitides. Characteristically in GCA, it is branches of the carotid and vertebral arteries that are preferentially affected by the inflammatory process. However, smaller vessels can also be affected: for example, often not just the ophthalmic artery with its extraparenchymal branches are affected, but also small ciliary arteries (2).

\section{Learning goals}

After reading this article, the reader should be able to

- recognize symptoms of giant cell arteritis,

- perform and evaluate the appropriate diagnostic tests, and

- initiate and monitor appropriate treatment.

\section{University Eye Hospital Freiburg: PD Dr. med. Ness \\ University Hospital Würzburg, Department of Radiology (Institut für Röntgen- diagnostik): Prof. Dr. med. Bley \\ Immanuel Krankenhaus Berlin, Rheumaklinik Berlin Buch: Prof. Dr. med. Schmidt}

Department of Rheumatology, Vasculitis Center UKSH \& Clinical Center Bad Bramstedt, University of Lübeck: Prof. Dr. med. Lamprecht

\author{
Giant cell arteritis \\ Characteristically, branches of the carotid \\ artery and the vertebral artery are involved in \\ the inflammatory process.
}


This article is based on a selective literature search of the PubMed database, and on the current guidelines and recommendations of the European (EULAR) and American (ACR) rheumatology societies, the British Society of Rheumatology (BSR), and the German Society of Internal Medicine (DGIM, Deutsche Gesellschaft für Innere Medizin).

\section{Epidemiology}

The incidence of GCA in Europe shows a marked north-south divide (e1-e4). In Germany, the incidence is stable at 3.5 per 100000 inhabitants per year in the over-50 age group (e5). Women are affected two to six times as often as men. Familial clustering is known (e6). After the age of 50, the incidence increases with age (e2).

\section{Etiology and pathogenesis}

The etiology of GCA is unknown. Because the incidence varies seasonally, and is higher in large conurbations, it has been suggested that environmental factors may be a trigger (e6, e7). Histologically, GCA is characterized by granulomatous inflammation with lymphocytes, macrophages, and giant cells (fused macrophages) in the vascular wall. The inflammatory edema and the vascular wall thickening can also be visualized with medical imaging techniques and can point toward the diagnosis. Stenosis or vascular occlusion may be seen, resulting from the vascular inflammation. Polymyalgia rheumatica (PMR) is regarded as a minor variant or subclinical form of GCA, on the basis of biopsy findings and the demonstration on positron emission tomography (PET) of discrete vascular accumulations in the subclavian arteries in both diseases. The proximal myalgia characteristic of PMR, however, is due to tenosynovitis in the hip and shoulder girdles and interspinal bursitis, which are independent pathological features of PMR (e10-e13).

\section{Clinical aspects}

The clinical symptoms are divided into those caused by cranial vascular involvement, those due to arteritis of large vessels, systemic inflammatory signs, and PMR (Table 1) (3, e8-e9).

\section{Cranial symptoms}

Bitemporal accentuated headaches refractory to analgesia occur in about three quarters of patients (3). Most patients report constant pain in the temporal region.

\section{TABLE 1}

\section{Symptoms in giant cell arteritis*}

\begin{tabular}{|c|c|}
\hline Category & Symptoms \\
\hline $\begin{array}{l}\text { Symptoms due to involvement of } \\
\text { cranial vessels }\end{array}$ & $\begin{array}{l}\text { Headache } \\
\text { Jaw claudication (pain on chewing) } \\
\text { Scalp tenderness } \\
\text { Loss of vision } \\
\text { Abnormalities of the temporal artery } \\
\text { (pain, nodules, absence of pulse) }\end{array}$ \\
\hline $\begin{array}{l}\text { Symptoms due to involvement of } \\
\text { great vessels (aorta and bran- } \\
\text { ches of aorta) }\end{array}$ & Claudication of extremities (especially arm) \\
\hline $\begin{array}{l}\text { Symptoms due to systemic } \\
\text { inflammation }\end{array}$ & Fever, night sweats, weight loss \\
\hline Polymyalgia rheumatica & $\begin{array}{l}\text { Mainly proximal myalgia and stiffness of the neck } \\
\text { and shoulder and pelvic girdles }\end{array}$ \\
\hline
\end{tabular}

Intermittent headache or headaches that vary over time are rarely reported. More specific symptoms are activity-related accentuated pain on chewing (jaw claudication), a result of ischemia of the chewing muscles. Swallowing claudication and pain in the tongue can also occur. Similarly specific are scalp tenderness and abnormalities in the area of the temporal artery (temporal artery tenderness, knotty swellings, absence of pulse). Scalp necrosis is rare. Cerebral ischemia resulting from inflammation affecting the territory of the vertebral, basilar, or carotid arteries affects $3 \%$ to $4 \%$ of patients. Inflammation of the intracranial vessels, however, is very rare $(3, \mathrm{e} 10)$. Around $20 \%$ to $25 \%$ of patients with GCA show polyneuropathy.

\section{Involvement of the aorta and great arteries}

PET imaging shows accumulations in the aorta and the great arteries in up to $83 \%$ of patients with GCA (4). As a result, aortic aneurysms and stenoses of the vessels branching off from the aorta may occur (5). Thoracic aortic aneurysms are 17 times more common in patients with GCA than in the age matched general population, and abdominal aneurysms 2.4 times more common. They affect about $20 \%$ of patients and are identified a median of 5.8 years after first diagnosis of GCA (e11). Stenoses of the cerebral arteries and the subclavian artery with claudication or steal syndrome, however, and aortic dissections, occur after a much shorter time

\section{Incidence}

In Germany the incidence is reported to be stable at 3.5 per 100000 inhabitants per year in the over-50s age group. Two to six times more women are affected than men. Familial clustering is known.

\section{Etiology}

The etiology of GCA is unknown. Because of seasonal variations and because incidence is higher in large conurbations, environmental factors are suspected as potential triggers. 
TABLE 2

\section{EULAR-ACR classification criteria for polymyalgia rheumatica*}

\begin{tabular}{|c|c|}
\hline Giant cell arteritis (GCA) & Polymyalgia rheumatica (PMR) \\
\hline $\begin{array}{l}\text { - Age over } 50 \text { years } \\
\text { - New onset of localized } \\
\text { headache }\end{array}$ & $\begin{array}{l}\text { - Morning stiffness }>45 \text { minutes ( } 2 \text { points) } \\
\text { - Rheumatic factor and/or anti-CCP-antibodies } \\
\text { negative ( } 2 \text { points) }\end{array}$ \\
\hline $\begin{array}{l}\text { - Abnormality of temporal artery } \\
\text { (temporal artery tenderness, } \\
\text { reduced pulsation) } \\
\text { - Raised ESR ( } \geq 50 \mathrm{~mm} / 1^{\text {st }} \text { hour) } \\
\text { - Abnormal arterial biopsy } \\
\text { (vasculitis with predominantly } \\
\text { mononuclear cell infiltration or } \\
\text { granulomatous inflammation or } \\
\text { evidence of giant cells) }\end{array}$ & $\begin{array}{l}\text { - Pelvic girdle pain or reduced hip mobility } \\
\text { (1 point) } \\
\text { - No other painful joint (1 point) } \\
\text { - Ultrasound: inflammatory changes in both } \\
\text { shoulders (including subdeltoid bursitis) (1 } \\
\text { point) } \\
\text { - Ultrasound: inflammatory changes in at least } \\
\text { one shoulder and hip joint (1 point) }\end{array}$ \\
\hline
\end{tabular}

${ }^{*}$ Classification as PMR requires 4 points (10); for giant cell arteritis (GCA), three criteria for the classification of GCA must be fulfilled.

Modified from (14). EULAR, European League Against Rheumatism; ACR, American College of Rheumatology; ESR, erythrocyte sedimentation rate; CCP, anti-cyclic citrullinated peptide antibodies

(median 1 year) $(6$, e12). Aortic involvement is associated with a 2.6 -fold increased mortality compared with an age-matched comparison population. In addition, cardiovascular and pulmonary events in these patients much more often lead to death (7). Ischemic complications can also be triggered by involvement of coronary or mesenteric arteries $(8, \mathrm{e} 8)$.

\section{Signs of systemic inflammation}

The systemic inflammatory reaction is accompanied by a number of non-specific symptoms such as exhaustion, fever, night sweats, and weight loss. If only the aorta and/or the great arteries are involved, with no ischemic symptoms, the above-mentioned symptoms and raised serological inflammatory markers may be the only signs of GCA. Hence, GCA is an important part of the differential diagnosis of fever of unknown origin (FUO), and of unexplained weight loss and/or unexplained increased erythrocyte sedimentation rate (ESR) or raised C-reactive protein (CRP).

\section{Polymyalgia rheumatica}

In $40 \%$ to $60 \%$ of patients, GCA is associated with polymyalgia rheumatica (PMR) (9). These two conditions have overlapping symptoms, and both have a marked acute-phase reaction and respond well to corticosteroids. Typical features of PMR are proximal myalgia and stiffness of the neck and the hip and/or shoulder girdle (3). The characteristic symptoms are emphasized in the 2012 PMR classification criteria of the European (EULAR) and American (ACR) rheumatology societies (Table 2) (10).

\section{Eye involvement}

The eye or eyes are affected in around $70 \%$ of patients with GCA (Box) (11, e13-e16). If not treated, in up to $60 \%$ of patients the second eye may become blind within a few days (e8, e17, e18). The most frequent eye manifestation in GCA is anterior ischemic optic neuropathy $(\mathrm{AION})$ resulting from inflammatory occlusion of the posterior ciliary arteries (Figure 1a) (11, e13). The occlusion manifests as a sudden, painless loss of vision and/or loss of visual field. The affected optic nerve is swollen and pale with few hemorrhages and "cotton-wool spots" (microinfarcts of the retinal nerve fiber layer). Clinically it is difficult to distinguish arteritic AION (AAION) from non-arteritic AION (NAAION), in which the swelling is more hyperemic and is associated with fewer cotton-wool spots $(11,12)$. Unlike in NAAION, in arteritic AION it is rare to find the typical altitudinal (horizontally limited) loss of visual field; more often there remains only a small island of visual field (11). Occlusion of a retinal central artery or arterial branch is much rarer than AION, but also leads to sudden painless loss of vision (Figure 1 b). In posterior ischemic optic neuropathy, the ischemia is so far behind the entry of the optic nerve into the eye that the morphology of the optic disk is unchanged (e19). Very rarely, ocular ischemic syndrome with ocular hypotension and ischemic iritis may occur due to complete occlusion of the ophthalmic artery or the internal carotid artery (e20). Precursors of ischemic occlusion in the eye are cotton-wool spots (a sign of locally impaired perfusion of the retina), or a patient reporting transient blindness (amaurosis fugax) (11, e21). Ischemia of the extraocular muscles or their nerves or of the brain stem will lead to double vision (e14).

While double vision improves once treatment is started, as a rule any loss of vision is irreversible (11, e17). Without adequate treatment, the second eye will go blind within 1 to 14 days: This must be prevented at all costs (e17). Especially feared is the silent or occult form of GCA, in which loss of vision is the first symptom $(11, \mathrm{e} 22)$. In this form, $4 \%$ of patients not only have none of the typical clinical manifestations, but also show no increase in CRP and ESR (13).

\section{Systemic signs of infection}

The systemic inflammatory reaction is accompanied by a number of non-specific symptoms such as exhaustion, fever, night sweats, and weight loss.

\section{Eye involvement}

The eye is involved in up to $70 \%$ of patients with GCA. If left untreated, in up to $60 \%$ of patients the second eye may also go blind within a few days. 


\section{Diagnosis}

GCA is diagnosed on the basis of the combination of symptoms, clinical findings, laboratory results, and diagnostic imaging $(3,11,12$, e16). The criteria for GCA published by the American College of Rheumatology (ACR) are intended to help distinguish GCA from other vasculitides for study purposes, and should not be mistaken for clinical diagnostic criteria. Nevertheless, they are useful for general orientation in everyday clinical routine (Table 2) $(3,14)$. Because a diagnosis may lead to long-term (in some cases life-long) steroid treatment, which can have serious adverse effects, while at the same time a failure or delay in diagnosis can result in bilateral blindness, every effort should be made to achieve a definitive diagnosis. In many cases this can be done by duplex sonography, without resorting to MRI and biopsy. Evaluation of initial treatment response alone is not sufficient. The same would be true of, for example, endocarditis, in the first instance.

\section{Clinical examination}

The clinical examination includes palpation of the temporal artery, auscultation of the arteries including the subclavian and axillary arteries, and bilateral blood pressure measurement in order to look for any onesided vascular stenosis (e23).

\section{Laboratory investigations}

In GCA, ESR is raised and so is CRP. These two investigations are non-specific, but are sensitive enough for everyday clinical routine (ESR: $77 \%$ to $86 \%$; CRP: $95 \%$ to $98 \%$ ). For ESR, mean values around $90 \mathrm{~mm}$ after 1 hour and for CRP $90 \mathrm{mg} / \mathrm{dL}$ are given (15). CRP values return to normal within the first week on steroid treatment (3). Both these parameters have a much reduced sensitivity in recurrences in patients recieving immunosuppressants (ESR: $12 \%$ to 58\%; CRP: 50\%) (3, e24). Other diseases and factors such as anemia, hypo- or hypergammaglobulinemia, malignant tumors, infections, or trauma should be included in the differential diagnosis when interpreting the ESR. Fewer than $5 \%$ of GCA cases fail to show associated raised serological inflammatory activity $(13,16,17$, e9, e25). In addition to the raised ESR and CRP, normochromic normocytic anemia, leukocytosis and/or thrombocytosis, and an increase in acute-phase proteins in serum albumin electrophoresis are indicators of the systemic inflammation. Antiferritin autoantibodies are found in the serum of about $90 \%$ of patients with un-

\section{Involvement of the eye in giant cell arteritis*}

\section{- Eye manifestations}

- Anterior ischemic optic neuropathy (AION or AAION)

- Posterior ischemic optic neuropathy (PION)

- Arterial occlusion (occlusion of a central artery, branch artery, or cilioretinal vessel)

- Amaurosis fugax

- "Cotton-wool spots" (microinfarcts of the retinal nerve fiber layer)

- Double vision (involvement of muscles, cranial nerves, or brainstem)

- Ocular ischemic syndrome (hypotension, iritis)

* modified from (11)

treated GCA. Since antiferritin autoantibodies also occur in other inflammatory/rheumatic diseases, their presence does not constitute proof of GCA.

\section{Color-coded duplex sonography}

With color-coded duplex sonography, the temporal arteries, extracranial vessels, and also the occipital, subclavian, and other arteries can be examined noninvasively for inflammation (18). A transducer of at least $9 \mathrm{MHz}$ is required. Inflammatory edema of the vascular wall will be shown as hypoechoic wall thickening ("halo") (Figure 2). Other indications are stenoses and occlusions of the affected vessels. In addition, duplex sonography provides clues to flow behavior (flow acceleration in the stenotic region), and can reveal any reversal of flow with inverse cerebral supply via the temporal artery, in which case biopsy is contraindicated. In the hands of an experienced sonographer, a 15 minute color-coded duplex ultrasound study has a sensitivity of $85 \%$ and a specificity over $90 \%$. The correlation with eye involvement in GCA is high. A positive finding makes the diagnosis of GCA highly probable, although a negative finding does not rule it out. The technique is high resolution $(0.1 \mathrm{~mm})$, but does depend on the experience of the investigator. In

\section{Red flags}

Advance warning of ischemic occlusion of the eye is provided by "cotton-wool spots" (signs of locally impaired retinal perfusion) or by the patient's reporting transient loss of vision (amaurosis fugax).

\section{Clinical examination}

The clinical examination should include palpation of the temporal artery, auscultation of arteries including the subclavian and axillary, and bilateral blood pressure determination, looking for a predominant unilateral vascular stenosis. 
Figure 1:

a) Anterior ischemic optic neuropathy (AION) with swelling of the optic disk

b) Central artery occlusion
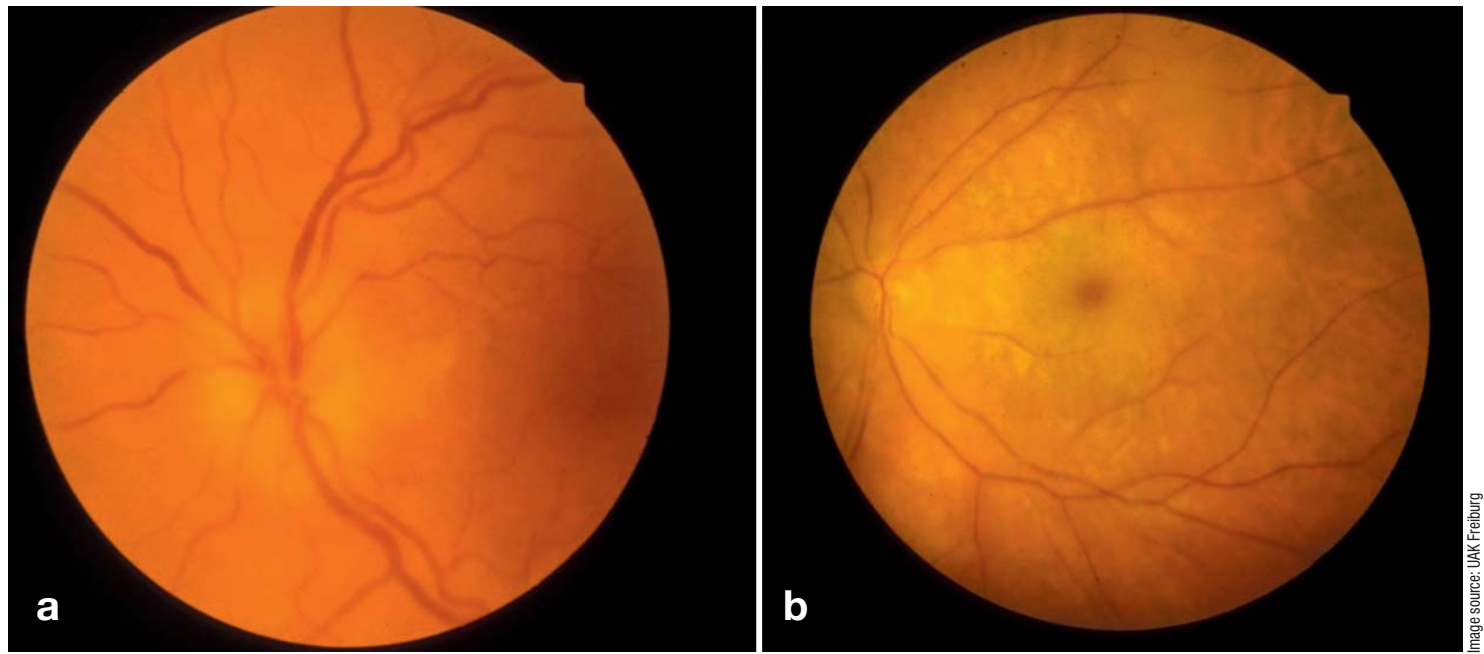

patients who have been on steroid treatment for two to three weeks, the halo is no longer visible (18).

\section{High-resolution magnetic resonance imaging (MRI)}

High-resolution MRI (fat saturation, T1-weighted spin echo sequence, resolution $195 \times 260 \mu \mathrm{m}$ ) allows detailed imaging of the walls and lumina of the superficial cranial arteries (Figure 3) (19-21). The studies can be performed with scanners from $1.5 \mathrm{~T}$ to (preferably) $3 \mathrm{~T}$. Wall segments that are swollen due to inflammation and take up contrast agent can be distinguished from unaffected segments of vessels (Figure 3). At the same time as visualizing the superficial temporal artery together with its branches, MRI allows an assessment of the superficial occipital arteries and the facial artery. In this way a picture may be gained of the pattern of cranial involvement (21). This is particularly helpful when planning a temporal biopsy, to locate a clearly inflamed vascular segment for the biopsy. In combination with MR angiography, within the same investigation evidence may be sought of involvement of the aorta, the supra-aortic arteries, and the great arteries of the viscera and extremities (e26). Once steroid therapy has been started, the signs of mural inflammation visible on MRI rapidly reduce $(22, \mathrm{e} 27)$

\section{Positron emission tomography (PET)}

PET is a medical imaging technique that uses radioactive isotopes to visualize metabolic processes.
Because inflammatory cells take up the marker 18fluoro-2 deoxy-D-glucose, this technique allows a sensitive representation of inflammatory processes in GCA. Spatial resolution is limited, however, so only the involvement of the larger arteries and aorta can be positively determined, but for this purpose the sensitivity is especially high. At the same time, PET covers a large scan volume, so that it is particularly suitable for whole body screening. The technique is usually performed in combination with computed tomography (PET-CT), which relates anatomic details from CT to the functional information on glucose metabolism gained with PET. However, the radiation exposure associated with the investigation (around 10 to $17 \mathrm{mSv}$ ) is non-negligible.

\section{Biopsy}

Temporal artery biopsy is still regarded as the diagnostic gold standard for GCA. It can be carried out as an outpatient procedure under local anesthesia. In addition to palpation, duplex sonography and, especially, high-resolution MRI help to identify a suitable site for biopsy. A biopsy specimen is taken on one side only; bilateral biopsy does not increase the diagnostic yield. A segment of artery about $2.5 \mathrm{~cm}$ long should be removed. The resection ends are ligated. Adequate perfusion is provided by collaterals. The complication rate (hematoma; wound infection; very rarely, facial paresis or cranial skin necrosis) is low (e16).

\section{Color-coded duplex sonography}

Color-coded duplex sonography allows the temporal artery, extracranial vessels, and also the occipital, subclavian, and other arteries to be visualized noninvasively and examined for signs of inflammation.

\section{Magnetic resonance imaging (MRI)}

With MRI, in addition to the superficial temporal artery and its branches, the superficial occipital and facial arteries can be assessed. In this way, a picture of the whole pattern of cranial involvement can be gained. 

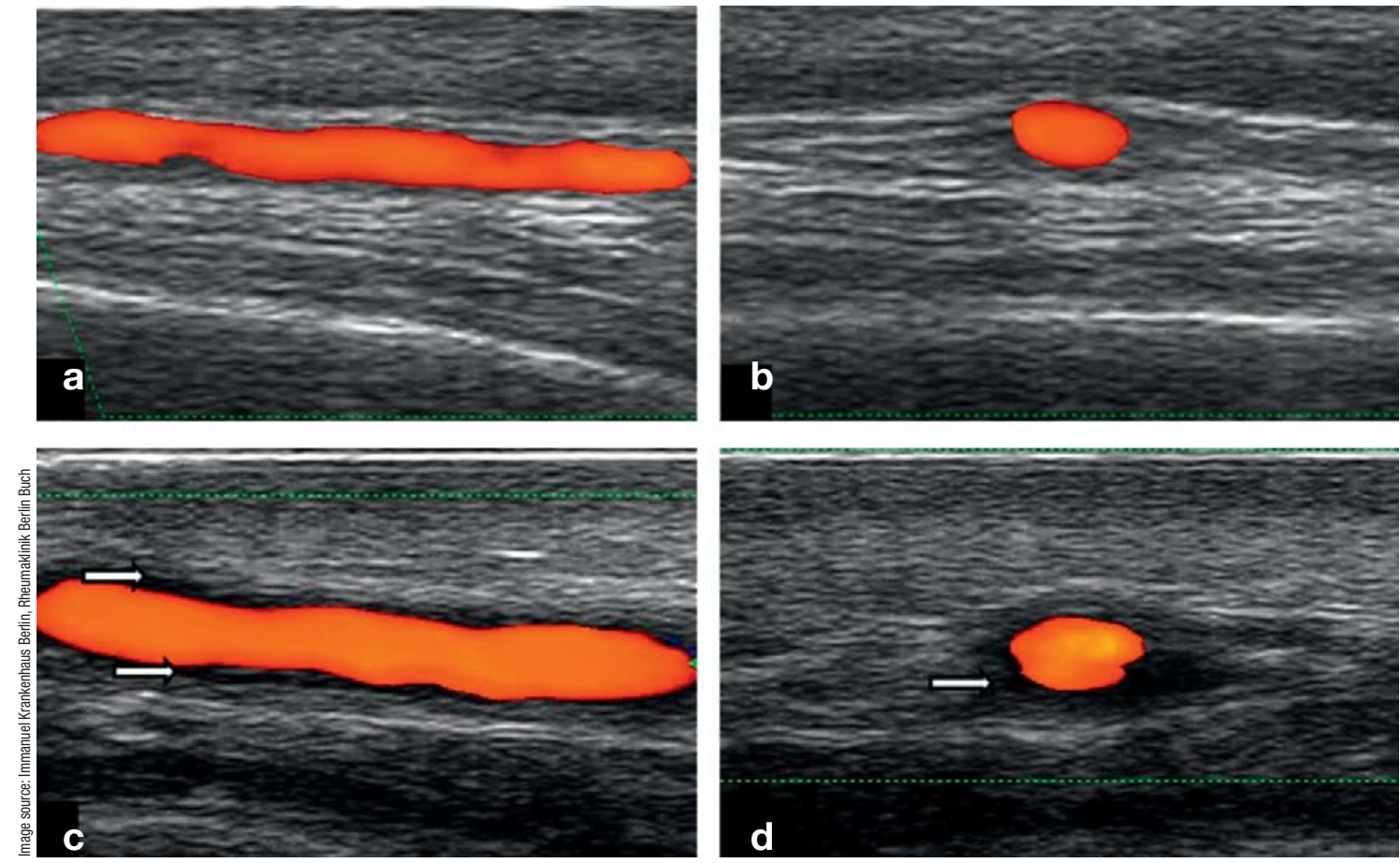

Histologically, GCA is characterized by inflammatory infiltration of the arterial wall by lymphocytes, macrophages, and giant cells (Figure 4). Multinucleated giant cells are demonstrated in about $50 \%$ of cases; that is, they are not constant findings. Typically, inflammation is found at the transition from the adventitia to the muscularis media (Figure 4), or it may be limited to just the adventitia or, more rarely, the vasa vasorum in the adventitia. As a result of the inflammation between the media and the intima, the lamina elastica interna is fragmented and the lumen shifted by intimal edema. The vascular wall is usually inflamed, not continuously, but in segments ("skip lesions") (23). A positive biopsy result is proof of GCA, but a negative result does not rule GCA out (e28). In 10\% to $25 \%$ of cases the biopsy result is a false negative (e29, e30). This may be because the biopsy sampled a noninflamed segment, or because it was carried out too long after the start of treatment (23). As a rule, however, GCA can be demonstrated by temporal artery biopsy up to at least 14 days after the start of treatment, and therefore steroid therapy, if indicated, should not be delayed until after planned biopsy or imaging (24, e31).

\section{Differential diagnoses}

The diagnosis of GCA rests on the combination of history and clinical, laboratory, imaging, and histological findings. A number of diseases whose symptoms and findings overlap with those of GCA should be included in the differential diagnosis (headache of other origin, unexplained raised ESR, other forms of vasculitis, polymyositis, non-arteritic AION, endocarditis). The question of whether GCA and PMR are associated with an increased risk of cancer is still under debate, but screening for a malignant tumor, as guided by symptoms and findings, should be carried out as part of the differential diagnostic work-up to clarify the raised $\operatorname{ESR}(25,26)$.

\section{Treatment}

Corticosteroids (evidence level 3, recommendation grade C)

The European League Against Rheumatism (EULAR) recommends starting corticosteroid treatment quickly, with an initial dosage of prednisolone $1 \mathrm{mg} / \mathrm{kg}$ body weight per day (max. $60 \mathrm{mg}$ ). Treatment should be started as soon as the clinical diagnosis has been
Figure 2:

Color-coded duplex sonography of the temporal artery: a) normal frontal branch, longitudinal and

b) transverse views; c) in acute temporal arteritis, showing hypoechoic wall thickening (arrows), longitudinal and d) transverse views

\section{Positron emission tomography (PET)}

The tracer 18-fluoro-2-deoxy-D-glucose accumulates in inflammatory cells, making PET a sensitive technique for imaging inflammatory processes in giant cell arteritis.

\section{Biopsy}

Biopsy of the temporal artery is still regarded as the diagnostic gold standard to confirm GCA. It can be carried out under local anesthesia as an outpatient procedure. 

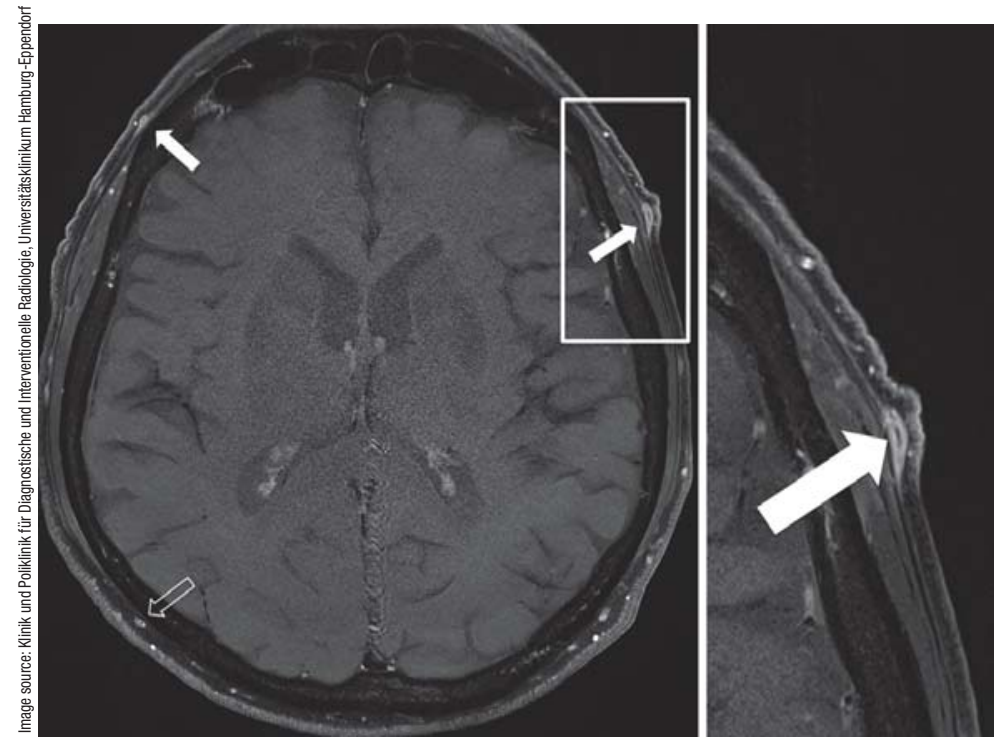

Figure 3: High-resolution 3-T MRI of the superficial cranial arteries of a 72-year-old man with giant cell arteritis. The frontal branch of the superficial temporal artery shows bilateral signs of wall inflammation (thickening, uptake of contrast agent) (solid arrow). The right superficial occipital artery likewise shows inflammatory changes (open arrow). Thanks to the high spatial resolution, details can be enlarged, giving a particularly good visualization of the wall changes (arrow in the inset detail of the frontal branch of the left temporal superficial artery)

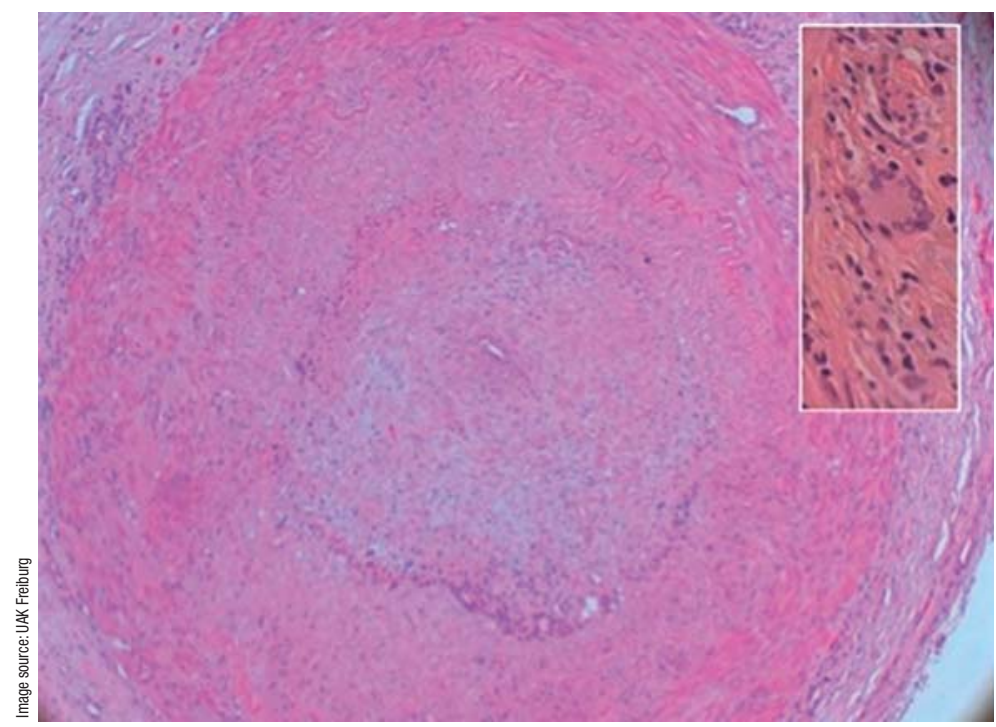

Figure 4: Inflamed temporal artery with intimal edema, cellular infiltration, and fragmented internal elastic membrane; box: typical giant cell with infiltration at the transition between intima and muscularis media in a temporal artery in a patient with giant cell arteritis made. As explained above, treatment should not be delayed by waiting to confirm the diagnosis by biopsy or imaging. One to two weeks after the start of treatment, the initial prednisolone dose can be reduced by $10 \mathrm{mg}$ steps every 1 to 2 weeks, depending on the patient's response to treatment; once the daily dose has dropped below $30 \mathrm{mg}$ prednisolone, the reduction can be in steps of $2.5 \mathrm{mg}$ every 2 weeks. From $10 \mathrm{mg} /$ day onwards, the reduction continues by $1 \mathrm{mg} / \mathrm{month}$ until the lowest effective dose is reached. The patient's progress is monitored on the basis of clinical symptoms, ESR, and CRP (Table 3) (3), and if there is any sign of relapse, the dose must be increased again. In $30 \%$ to $50 \%$ of all cases the dose needs to be increased again despite an initially good response (e32). After a mean duration of treatment of 2 years, cessation of treatment may be attempted $(12,27,28)$. However, for many patients $(20 \%$ to $25 \%)$, steroid treatment has to be continued for much longer, in some cases for life (8, e33, e34).

For patients with cerebral or ocular symptoms, some authors recommend an initial intravenous high-dose treatment (methylprednisolone 250 to $1000 \mathrm{mg}$ /day for 3 to 5 days), after which treatment can be continued orally at the dosage recommended by EULAR (29, e16). The efficacy of the high-dose treatment is disputed $(30,31)$. In a patient with amaurosis fugax, however, the risk of bilateral blindness should prompt high-dose treatment (11, 29, 32). Although the general symptoms improve within a few days with corticosteroid treatment, the loss of vision, with few exceptions, is irreversible (11). In up to $60 \%$ of patients, without treatment the second eye will go blind within a few days, whereas if treatment is given, second-eye blindness will occur in $10 \%$ to $20 \%$ (e17, e18).

Corticosteroid treatment in the affected age group, if continued for a long time, is associated with a number of adverse effects. Within 10 years, $86 \%$ of treated patients developed adverse effects $(28,32$, e35, e36). Some of the frequent complications are: steroid-induced diabetes, arterial hypertension, cataract, and osteoporosis. One case of sudden death has been reported when a fast infusion speed was used (e37). Vitamin D to prevent osteoporosis is recommended (e38). Treatment to prevent gastric ulcer is recommended only for patients with a history of gastric ulcer, or those concurrently receiving nonsteroidal anti-inflammatory drugs (NSAIDs) or acetylsalicylic acid.

\section{Differential diagnosis}

The diagnosis of GCA rests on a combination of patient history and clinical, laboratory, imaging, and histological findings. A number of diseases show overlapping symptoms and findings.

\section{Biopsy findings}

Typically, inflammation is found at the transition between the adventitia and the muscularis media. 


\section{Methotrexate (evidence level $1 \mathrm{~A}$, recommendation grade $\mathrm{B}$ )}

Within 2 years, $30 \%$ to $50 \%$ of patients suffer a relapse despite initially responding well to corticosteroid treatment (e32, e33).

A meta-analysis of three randomized controlled studies testing the efficacy of methotrexate (7.5 to 15 $\mathrm{mg} /$ week) as a steroid-sparing co-medication showed a reduction in the relapse rate and a lower cumulative dose of steroid from the $24^{\text {th }}$ week onwards in the patients given MTX (33).

Treatment with methotrexate is therefore recommended by EULAR (27). A small randomized controlled study also showed a steroid-sparing effect for azathioprine (150 mg/day) (34). Azathioprine offers an alternative to methotrexate treatment in patients with contraindications or who do not tolerate methotrexate (8, e34).

\section{Biologicals (evidence level 2, recommendation grade C)}

Various biologicals (e.g., anti-TNF- $\alpha$, anti-CD20, antiinterleukin receptor antibodies) have been investigated in case studies and series. The efficacy of biologicals in GCA cannot, however, be adequately judged on the basis of current data, and they should therefore not be used at present except in clinical studies $(27,35,36)$.

Acetylsalicylic acid (evidence level 3, recommendation grade C) In animal experiments, acetylsalicylic acid (ASA) inhibits cytokine transcription in the inflamed arterial wall in GCA. Since GCA is also associated with vascular occlusions, especially in the eye, and with thrombocytosis, EULAR recommends giving ASA (75 to 150 $\mathrm{mg} /$ day) as a platelet aggregation inhibitor, in the absence of contraindications. Retrospective analyses have reported a protective effect on cardiovascular and cerebrovascular events in $\operatorname{GCA}(37,38)$. When ASA is given in combination with corticosteroids, a proton pump inhibitor should also be given to prevent gastric ulcers.

\section{Conflict of interest statement}

Dr. Ness has received fees for carrying out studies commissioned by Novartis, Abbott (Abbvie), Santen, and Allergan.

Professor Bley has received third-party funding from Bracco. He has received consultancy fees from Bayer, Bracco, GE, Guerbet, Intercom, Siemens, and Medicorum.

Professor Schmidt and Professor Lamprecht declare that no conflict of interest exists.

Manuscript received on 12 0ctober 2012, revised version accepted on 3 April 2013.

Translated from the original German by Kersti Wagstaff, MA.

\section{Starting treatment}

Treatment should not be delayed while waiting for confirmation of the diagnosis by biopsy or imaging studies.
TABLE 3

Practical recommendations for the diagnosis, treatment, and follow-up of giant cell arteritis*

\begin{tabular}{l|l}
\hline Suspect giant cell arteritis (GCA) if \\
\hline Patient is older than 50 years & - Newly occurring headache \\
with the following symptoms & - Scalp tenderness \\
& - Jaw and tongue pain \\
& - Visual disturbances \\
& - General symptoms (fever, night sweats, weight \\
& loss) \\
& - Polymyalgia rheumatica \\
& - Claudication of extremities \\
& - Raised inflammation values \\
\hline Examination shows & - Temporal artery abnormalities \\
& - AION, central artery occlusion
\end{tabular}

Recommended diagnostic tests

\begin{tabular}{l|l} 
Blood tests & $\begin{array}{l}\text { ESR, C-reactive protein, blood count, } \\
\text { serum albumin electrophoresis }\end{array}$ \\
\hline $\begin{array}{l}\text { Confirmation of diagnosis } \\
\text { (any of the following) }\end{array}$ & Doppler ultrasound, MRI, biopsy \\
\hline
\end{tabular}

Treatment

Start treatment immediately on - Giant cell arteritis without visual symptoms or clinical suspicion

other vascular complications
- max. $60 \mathrm{mg}$ prednisolone until symptoms disappear and blood parameters normalize

- Giant cell arteritis with visual symptoms or other vascular complications

- Start with 3 days methylprednisolone 0.5 to $1 \mathrm{~g}$ intravenously

\begin{tabular}{|c|c|}
\hline $\begin{array}{l}\text { Reduce glucocorticoid therapy } \\
\text { Provided no active disease, } \\
\text { no relapse during reduction }\end{array}$ & $\begin{array}{l}\text { - Max. } 60 \mathrm{mg} \text { prednisolone for } 1-2 \text { weeks } \\
\text { - Reduce by } 10 \mathrm{mg} \text { every } 1-2 \text { weeks down to } \\
30 \mathrm{mg} \\
\text { - Then reduce by } 2.5 \mathrm{mg} \text { every } 2 \text { weeks down to } \\
10 \mathrm{mg} \\
\text { - Then reduce by } 1 \mathrm{mg} \text { per month }\end{array}$ \\
\hline Start steroid-sparing treatment & $\begin{array}{l}\text { Methotrexate (MTX) (15-25 mg/week); } \\
\text { if MTX contraindicated or not tolerated, } \\
\text { azathioprine as alternative }\end{array}$ \\
\hline Additive treatment & $\begin{array}{l}\text { Acetylsalicylic acid (ASA), } \\
\text { osteoporosis prevention (vitamin D) }\end{array}$ \\
\hline \multicolumn{2}{|l|}{ Treatment monitoring } \\
\hline \multicolumn{2}{|c|}{$\begin{array}{l}\text { - Monitor symptoms } \\
\text { - Monitor adverse effects of corticosteroids } \\
\text { - Blood tests (ESR, C-reactive protein, blood count, glucose) } \\
\text { - Imaging techniques: every } 2 \text { years chest radiograph (aortic aneurysm), other } \\
\text { imaging if required } \\
\text { - Follow-ups during } 1^{\text {st }} \text { year (weeks } 0,1,3,6 \text {, then months } 3,6,9,12 \text { ) and if new } \\
\text { symptoms or adverse effects occur }\end{array}$} \\
\hline
\end{tabular}

*According to: EULAR, European League Against Rheumatism; BSR, British Society of Rheumatology $(27,40)$. ESR, ervthrocyte sedimentation rate;

\section{Dosage}

For patients with cerebral or ocular symptoms, some authors recommend initial high-dose intravenous treatment with methylprednisolone. 


\section{GASE ILLUSTRATION}

A 78-year-old woman has been suffering from temporal headache for 13 days. Analgesics do not relieve the pain. Since this morning, she has noticed a loss of the lower half of the visual field in the left eye, with loss of visual acuity. On being questioned, she reports pain on chewing and slight fever. Blood tests show an ESR of $80 \mathrm{~mm}$ after 1 hour, CRP is $67 \mathrm{mg} / \mathrm{dL}$, and fibrinogen $687 \mathrm{mg} / \mathrm{dL}$. Eye examination reveals AION (anterior ischemic optic neuropathy) and visual acuity reduced to the perception of hand movements. With a suspected diagnosis of giant cell arteritis, treatment is started with prednisolone $4 \times 250 \mathrm{mg}$ per day intravenously for 3 days, then $60 \mathrm{mg}$ per day orally. At the same time, confirmation of diagnosis is sought with duplex ultrasound and temporal artery biopsy. With treatment, the symptoms improve and blood results normalize, but the loss of visual field and visual acuity remain.

\section{REFERENCES}

1. Horton BT, Magath TB, Brown GE: An undescribed form of arteritis of the temporal vessels. Proc Mayo Clin 1932; 7: 700-1.

2. Jennette JC, Falk RJ, Andrassy K, et al.: Nomenclature of systemic vasculitides. Proposal of an international consensus conference. Arthritis Rheum 1994; 37: 187-92.

3. Vaith $P$, Warnatz K: Clinical and serological findings of giant-cell arteritis. Z Rheumatol 2009; 68: 124-31.

4. Blockmans D: The use of (18F)fluoro-deoxyglucose positron emission tomography in the assessment of large vessel vasculitis. Clin Exp Rheumatol 2009; 21: 15-22.

5. Nuenninghoff DM, Hunder GG, Christianson TJ, McClelland RL, Matteson EL: Mortality of large-artery complication (aortic aneurysm, aortic dissection, and/or large-artery stenosis) in patients with giant cell arteritis: a population-based study over 50 years. Arthritis Rheum 2003; 48: 3532-7.

6. Nuenninghoff DM, Hunder GG, Christianson TJ, McClelland RL, Matteson EL: Incidence and predictors of large-artery complication (aortic aneurysm, aortic dissection, and/or large-artery stenosis) in patients with giant cell arteritis: a population-based study over 50 years. Arthritis Rheum 2003; 48: 3522-31.

7. Kermani TA, Warrington KJ, Crowson CS, Ytterberg SR, Hunder GG, Gabriel SE, Matteson EL: Large-vessel involvement in giant cell arteritis: a population-based cohort study of the incidence-trends and prognosis. Ann Rheum Dis 2012 Dec 19. [Epub ahead of print].

8. Vaith P, Bley T: Primär systemische Vaskulitiden - große Gefäße. In: Peter HH, Pichler WJ, Müleer-Ladner (eds): Klinische Immunologie. $3^{\text {rd }}$ edition. München: Urban \& Fischer 2012; 363-9.
9. Salvarani C, Cantini F, Boiardi L, Hunder GG: Polymyalgia rheumatica and giant-cell arteritis. N Engl J Med 2002; 347: 261-71.

10. Dasgupta B, Cimmino MA, Maradit-Kremers H, et al.: 2012 provisional classification criteria for polymyalgia rheumatica: a European League Against Rheumatism/American College of Rheumatology collaborative initiative. Ann Rheum Dis 2012; 71: 484-92.

11. Ness T, Auw-Hadrich C, Schmidt D: Temporal arteritis (giant cell arteritis). Clinical picture, histology, and treatment. Ophthalmologe 2006; 103: 296-301

12. Kale N, Eggenberger $\mathrm{E}$ : Diagnosis and management of giant cell arteritis: a review. Curr Opin Ophthalmol 2010; 21: 417-22.

13. Kermani TA, Schmidt J, Crowson CS, et al.: Utility of erythrocyte sedimentation rate and $\mathrm{C}$-reactive protein for the diagnosis of giant cell arteritis. Semin Arthritis Rheum 2012; 41: 866-71.

14. Hunder GG, Bloch DA, Michel BA, et al.: The American College of Rheumatology 1990 criteria for the classification of giant cell arteritis. Arthritis Rheum 1990; 33: 1122-8.

15. Gonzalez-Gay MA, Lopez-Diaz MJ, Barros S, et al.: Giant cell arteritis: laboratory tests at the time of diagnosis in a series of $240 \mathrm{pa}-$ tients. Medicine 2005; 84: 277-90.

16. Ciccarelli M, Jeanmonod D, Jeanmonod R: Giant cell temporal arteritis with a normal erythrocyte sedimentation rate: report of a case. Am J Emerg Med 2009; 27: 255: e1-3.

17. Parikh M, Miller NR, Lee AG, et al.: Prevalence of a normal C-reactive protein with an elevated erythrocyte sedimentation rate in biopsy-proven giant cell arteritis. Ophthalmology 2006; 113: 1842-5.

18. Schmidt WA, Kraft HE, Vorpahl K, Volker L, Gromnica-Ihle EJ: Color duplex ultrasonography in the diagnosis of temporal arteritis. N Engl J Med 1997; 337: 1336-42.

19. Bley TA, Uhl M, Carew J, et al.: Diagnostic value of high-resolution MR imaging in giant cell arteritis. AJNR Am J Neuroradiol 2007; 28: 1722-7.

20. Bley TA, Wieben 0, Uhl M, Thiel J, Schmidt D, Langer M: High-resolution MRI in giant cell arteritis: imaging of the wall of the superficial temporal artery. AJR Am J Roentgenol 2005; 184: 283-7.

21. Bley TA, Wieben 0 , Vaith P, Schmidt D, Ghanem NA, Langer M: Magnetic resonance imaging depicts mural inflammation of the temporal artery in giant cell arteritis. Arthritis Rheum 2004; 51 : 1062-1063; author reply 1064.

22. Hauenstein C, Reinhard M, Geiger J, et al.: Effects of early corticosteroid treatment on magnetic resonance imaging and ultrasonography findings in giant cell arteritis. Rheumatology 2012; 51: 1999-03.

23. Poller $D N$, van Wyk $Q$, Jeffrey MJ: The importance of skip lesions in temporal arteritis. J Clin Pathol 2000; 53: 137-9.

24. Zhou L, Luneau K, Weyand CM, Biousse V, Newman NJ, Grossniklaus HE: Clinicopathologic correlations in giant cell arteritis: a retrospective study of 107 cases. Ophthalmology 2009; 116: 1574-80.

25. Ji J, Liu X, Sundquist K, Sundquist J, Hemminki K: Cancer risk in patients hospitalized with polymyalgia rheumatica and giant cell arteritis: a follow-up study in Sweden. Rheumatology 2010; 49: 1158-63.

26. Kermani TA, Schafer VS, Crowson CS, et al.: Malignancy risk in patients with giant cell arteritis: a population-based cohort study. Arthritis Care Res 2010; 62: 149-54.

\section{Biologicals}

Existing data do not allow the efficacy of biologicals in GCA to be evaluated. For the time being, therefore, they should not be used except in clinical studies.

\section{Acetylsalicylic acid}

Retrospective analyses have shown a protective effect on cardiovascular and cerebrovascular events in GCA. 
27. Mukhtyar C, Guillevin L, Cid MC: EULAR recommendations for the management of large vessel vasculitis. Ann Rheum Dis 2009; 68: 318-23.

28. Proven A, Gabriel SE, Orces C, O'Fallon WM, Hunder GG: Glucocorticoid therapy in giant cell arteritis: duration and adverse outcomes. Arthritis Rheum 2003; 49: 703-8.

29. Mazlumzadeh M, Hunder GG, Easley KA, et al.: Treatment of giant cell arteritis using induction therapy with high-dose glucocorticoids: a double-blind, placebo-controlled, randomized prospective clinical trial. Arthritis Rheum 2006; 54: 3310-8

30. Chevalet $P$, Barrier JH, Pottier $P$, et al.: A randomized, multicenter, controlled trial using intravenous pulses of methylprednisolone in the initial treatment of simple forms of giant cell arteritis: a one year followup study of 164 patients. J Rheumatol 2000; 27: 1484-91.

31. Hayreh SS, Zimmerman B: Visual deterioration in giant cell arteritis patients while on high doses of corticosteroid therapy. Ophthalmology 2003; 110: 1204-15.

32. Wipfler-Freissmuth E, Loock J, Moosig F, Dejaco C, Duftner C, Schirmer M: Current therapeutic options for giant cell arteritis. Z Rheumatol 2009; 68: 132-6.

33. Mahr AD, Jover JA, Spiera RF, et al.: Adjunctive methotrexate for treatment of giant cell arteritis: an individual patient data meta-analysis. Arthritis Rheum 2007; 56: 2789-97.

34. De Silva M, Hazleman BL: Azathioprine in giant cell arteritis/polymyalgia rheumatica: a double-blind study. Ann Rheum Dis 1986; 45: 136-8.

35. Hoffman GS, Cid MC, Rendt-Zagar KE, et al.: Infliximab for maintenance of glucocorticosteroid-induced remission of giant cell arteritis: a randomized trial. Ann Intern Med 2007; 146: 621-30.

36. Martinez-Taboada VM, Rodriguez-Valverde V, Carreno L, et al.: A double-blind placebo controlled trial of etanercept in patients with giant cell arteritis and corticosteroid side effects. Ann Rheum Dis 2008; 67: 625-30.

37. Lee MS, Smith SD, Galor A, Hoffman GS: Antiplatelet and anticoagulant therapy in patients with giant cell arteritis. Arthritis Rheum 2006; 54 : 3306-9.

38. Nesher G, Berkun Y, Mates M, Baras M, Rubinow A, Sonnenblick M: Low-dose aspirin and prevention of cranial ischemic complications in giant cell arteritis. Arthritis Rheum 2004; 50: 1332-7.

39. Ness T, Schmidt D: Arteriitis temporalis: Temporalarterienbiopsie, Anamnese und Blutwerte. Zeitschrift für praktische Augenheilkunde 2005; 26: $327-32$

\section{FURTHER INFORMATION ON GME}

This article has been certified by the North Rhine Academy for Postgraduate and Continuing Medical Education.

Deutsches Ärzteblatt provides certified continuing medical education (CME) in accordance with the requirements of the Medical Associations of the German federal states (Länder). CME points of the Medical Associations can be acquired only through the Internet, not by mail or fax, by the use of the German version of the CME questionnaire. See the following website: cme.aerzteblatt.de

Participants in the CME program can manage their CME points with their 15-digit "uniform CME number" (einheitliche Fortbildungsnummer, EFN). The EFN must be entered in the appropriate field in the cme.aerzteblatt.de website under "meine Daten" ("my data"), or upon registration.

The EFN appears on each participant's CME certificate.

The present CME unit can be accessed until 18 August 2013.

The CME unit "The prevention, diagnosis and treatment of premature labor" (issue 13/2013) can be accessed until 30 June 2013.

The CME unit "The Diagnosis and Treatment of Generalized Anxiety Disorder" (issue 17/2013) can be accessed until 21 July 2013.

40. Dasgupta B, Borg FA, Hassan N, et al.: BSR and BHPR quidelines for the management of giant cell arteritis. Rheumatology 2010; 49: $1594-7$.

\section{Corresponding autho}

PD Dr. Thomas Ness

Universitäts-Augenklinik Freibur

Killianstr. 5, 79106 Freiburg, Germany

thomas.ness@uniklinik-freiburg.de

For eReferences please refer to www.aerzteblatt-international.de/ref2113 


\section{Please answer the following questions to participate in our certified Continuing Medical Education program. Only one answer is possible per question. Please select the answer that is most appropriate.}

Question 1

What is the estimated incidence of giant cell arteritis in Germany?
a) 2.5 per 100000 people over the age of 40
b) 3.5 per 100000 people over the age of 50
c) 4.5 per 100000 people over the age of 60
d) 5.5 per 100000 people over the age of 70
e) 6.5 per 100000 people over the age of 80

\section{Question 2}

Which symptoms should prompt a suspected diagnosis of giant cell arteritis?

a ) New onset of headache, jaw claudication, scalp tenderness, visual impairment

b) Pain in the distal finger joints, morning stiffness

c) Sensory disturbances in the lower extremities, intermittent claudication

d) Flashing lights, floaters, and slowly progressive visual loss

e) Chest pain, shortness of breath

Question 3

What is the typical form of eye involvement in GCA?

a) Retinal detachment

b) Macular degeneration

c) Narrow-angle glaucoma

d) Acute anterior uveitis

e) Anterior ischemic optic neuropathy (AION)

\section{Question 4}

What is the classification criterion for giant cell arteritis according to the EULAR-ACR classification?

a) Rheumatoid factor negative

b) Reduced hip mobility

c) Absence of joint pain

d) Raised erythrocyte sedimentation rate ( $\geq 50 \mathrm{~mm} / 1^{\text {st }}$ hour)

e) Morning stiffness $>45$ minutes

\section{Question 5}

Which imaging technique has the highest resolution

$(0.1 \mathrm{~mm})$ for showing vascular changes?

a) High-resolution magnetic resonance imaging

b) Positron emission tomography

c) Cranial $x$-ray

d) Color-coded duplex sonography

e) Digital subtraction angiography
Question 6

What is the typical biopsy finding when a suspected diagnosis of giant cell arteritis is confirmed?
a) Basophilic granulocytes
b) Raised red blood cell count
c) Inflammation at the transition between the adventitia and the muscularis media
d) Raised fibrinogen level
e) Continuous inflammation of the vascular wall

\section{Question 7}

According to the European League Against Rheumatism, what is the drug of choice in the treatment of giant cell arteritis?
a) A corticosteroid
b) Methotrexate
c) Rituximab
d) Infliximab
e) Azathioprine

Question 8

What additive treatment is recommended?
a) Antibiotics
b) Acetylsalicylic acid
c) Coumarin derivatives
d) Nonsteroidal anti-inflammatories
e) Antimycotics

Question 9

How long is the estimated average duration of medical treatment for giant cell arteritis?
a) 3 months
b) 6 months
c) 9 months
d) 1 year
e) 2-3 years or longer

Question 10

What is one of the frequent adverse effects seen in patients in the age group affected with giant cell arteritis, that is due to long-term treatment with corticoids?
a) Alopecia areata
b) Urticaria
c) Bronchial asthma
d) Osteoporosis
e) Acne vulgaris 


\title{
CONTINUING MEDICAL EDUCATION
}

\section{The Diagnosis and Treatment of Giant Cell Arteritis}

\author{
Thomas Ness, Thorsten A. Bley, Wolfgang A. Schmidt, Peter Lamprecht,
}

\section{EREFERENCES}

e1. Boesen P, Sorensen SF: Giant cell arteritis, temporal arteritis, and polymyalgia rheumatica in a Danish county. A prospective investigation, 1982-1985. Arthritis Rheum 1987; 30: 294-9.

e2. Gonzalez-Gay MA, Miranda-Filloy JA, Lopez-Diaz MJ, et al.: Giant cell arteritis in northwestern Spain: a 25-year epidemiologic study. Medicine 2007; 86: 61-8.

e3. Gran JT, Myklebust G: The incidence of polymyalgia rheumatica and temporal arteritis in the county of Aust Agder, south Norway: a prospective study 1987-94. J Rheumatol 1997; 24: 1739-43.

e4. Noltorp S, Svensson B: High incidence of polymyalgia rheumatica and giant cell arteritis in a Swedish community. Clin Exp Rheumatol 1991; 9: $351-5$.

e5. Reinhold-Keller E, Herlyn K, Wagner-Bastmeyer R, Gross WL: Stable incidence of primary systemic vasculitides over five years: results from the German vasculitis register. Arthritis Rheum 2005; 53: 93-9.

e6. Salvarani C, Gabriel SE, O'Fallon WM, Hunder GG: The incidence of giant cell arteritis in Olmsted County, Minnesota: apparent fluctuations in a cyclic pattern. Ann Intern Med 1995; 123: 192-4.

e7. Wagner AD: Giant cell arteritis (temporal arteritis). Pathophysiology, immunology. Ophthalmologe 2006; 103: 302-7.

e8. Salvarani C, Cantini F, Hunder GG: Polymyalgia rheumatica and giantcell arteritis. Lancet 2008; 372: 234-45.

e9. Schmidt J, Warrington KJ: Polymyalgia rheumatica and giant cell arteritis in older patients: diagnosis and pharmacological management. Drugs Aging 2011; 28: 651-66.

e10. Chew SS, Kerr NM, Danesh-Meyer HV: Giant cell arteritis. J Clin Neurosci 2009; 16: 1263-8.

e11. Evans JM, O'Fallon WM, Hunder GG: Increased incidence of aortic aneurysm and dissection in giant cell (temporal) arteritis. A population-based study. Ann Intern Med 1995; 122: 502-7.

e12. Maksimowicz-McKinnon K, Clark TM, Hoffman GS: Takayasu arteritis and giant cell arteritis: a spectrum within the same disease? Medicine 2009; 88: 221-6.

e13. Gonzalez-Gay MA, Garcia-Porrua C, Llorca J, et al.: Visual manifestations of giant cell arteritis. Trends and clinical spectrum in 161 patients. Medicine 2000; 79: 283-92.

e14. Hayreh SS, Podhajsky PA, Zimmerman B: Ocular manifestations of giant cell arteritis. Am J Ophthalmol 1998; 125: 509-20.

e15. Ness T, Schmidt D: Arteriitis temporalis: Temporalarterienbiopsie, Anamnese und Blutwerte. Zeitschrift für praktische Augenheilkunde 2005; 26: 327-32.

e16. Rahman W, Rahman FZ: Giant cell (temporal) arteritis: an overview and update. Surv Ophthalmol 2005; 50: 415-28.

e17. Aiello PD, Trautmann JC, McPhee TJ, Kunselman AR, Hunder GG: Visual prognosis in giant cell arteritis. Ophthalmology 1993; 100: 550-5.

e18. Jonasson F, Cullen JF, Elton RA: Temporal arteritis. A 14-year epidemiological, clinical and prognostic study. Scott Med J 1979; 24: $111-7$.

e19. Hayreh SS: Posterior ischaemic optic neuropathy: clinical features, pathogenesis, and management. Eye 2004; 18: 1188-206.

e20. Schmidt D: Ocular ichemia syndrome — a malignant course of giant cell arteritis. Eur J Med Res 2005; 10: 233-42. e21. Gonzalez-Gay MA, Blanco R, Rodriguez-Valverde V, et al.: Permanent visual loss and cerebrovascular accidents in giant cell arteritis: predictors and response to treatment. Arthritis Rheum 1998; 41 : 1497-504.

e22. Hayreh SS, Podhajsky PA, Zimmerman B: Occult giant cell arteritis: ocular manifestations. Am J Ophthalmol 1998; 125: 521-6.

e23. Schmidt WA, Gromnica-lhle E: What is the best approach to diagnosing large-vessel vasculitis? Best Pract Res Clin Rheumatol 2005 19: 223-42.

e24. Salvarani C, Cantini F, Boiardi L, Hunder GG: Laboratory investigations useful in giant cell arteritis and Takayasu's arteritis. Clin Exp Rheumatol 2003; 21: 23-8.

e25. Weyand CM, Fulbright JW, Hunder GG, Evans JM, Goronzy JJ: Treatment of giant cell arteritis: interleukin- 6 as a biologic marker of disease activity. Arthritis Rheum 2000; 43: 1041-8.

e26. Markl M, Uhl M, Wieben 0, et al.: High resolution 3T MRI for the assessment of cervical and superficial cranial arteries in giant cell arteritis. J Magn Reson Imaging 2006; 24: 423-7.

e27. Bley TA, Markl M, Schelp M, et al.: Mural inflammatory hyperenhancement in MRI of giant cell (temporal) arteritis resolves under corticosteroid treatment. Rheumatology 2008; 47: 65-7.

e28. Hayreh SS, Podhajsky PA, Raman R, Zimmerman B: Giant cell arteritis: validity and reliability of various diagnostic criteria. Am J Ophthalmol 1997; 123: 285-96.

e29. Bhatti MT, Tabandeh H: Giant cell arteritis: diagnosis and management. Curr Opin Ophthalmol 2001; 12: 393-9.

e30. Weyand CM, Bartley GB: Giant cell arteritis: new concepts in pathogenesis and implications for management. Am J Ophthalmol 1997; 123: 392-5.

e31. Achkar AA, Lie JT, Hunder GG, O'Fallon WM, Gabriel SE: How does previous corticosteroid treatment affect the biopsy findings in giant cell (temporal) arteritis? Ann Intern Med 1994; 120: 987-92.

e32. Andersson R, Malmvall BE, Bengtsson BA: Long-term corticosteroid treatment in giant cell arteritis. Acta Med Scand 1986; 220: 465-9.

e33. Salvarani C, Macchioni PL, Tartoni PL, et al.: Polymyalgia rheumatica and giant cell arteritis: a 5-year epidemiologic and clinical study in Reggio Emilia, Italy. Clin Exp Rheumatol 1987; 5: 205-15.

e34. Vaith P, Bley T: Primär systemische Vaskulitiden - große Gefäße. In: Peter HH, Pichler WJ, Müller-Ladner (eds): Klinische Immunologie. $3^{\text {rd }}$ edition München: Urban \& Fischer 2012; 363-9.

e35. Nesher G, Rubinow A, Sonnenblick M: Efficacy and adverse effects of different corticosteroid dose regimens in temporal arteritis: a retrospective study. Clin Exp Rheumatol 1997; 15: 303-6.

e36. Nesher G, Sonnenblick M, Friedlander Y: Analysis of steroid related complications and mortality in temporal arteritis: a 15-year survey of 43 patients. J Rheumatol 1994; 21: 1283-6.

e37. Gardiner PV, Griffiths ID: Sudden death after treatment with pulsed methylprednisolone. BMJ 1990; 300: 125.

e38. Saag KG, Emkey R, Schnitzer TJ, Brown JP, et al.: Alendronate for the prevention and treatment of glucocorticoid-induced osteoporosis. Glucocorticoid-Induced Osteoporosis Intervention Study Group. N Engl J Med 1998; 339: 292-9. 